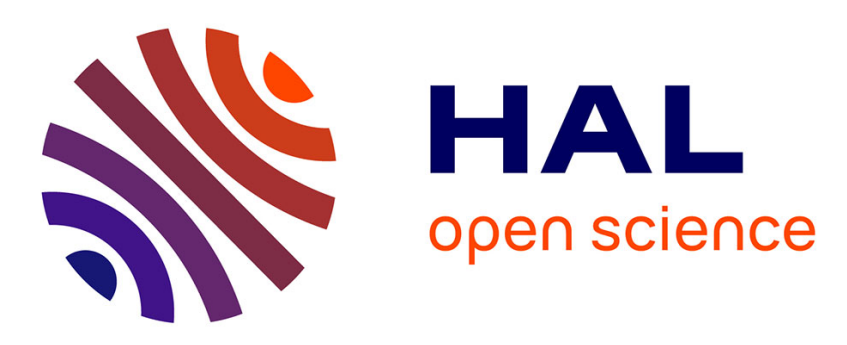

\title{
Rhizobium gallicum as an efficient symbiont for bean cultivation
}

Bacem Mnasri, Fatma Tajini, Mustapha Trabelsi, Mohamed Elarbi Aouani, Ridha Mhamdi

\section{- To cite this version:}

Bacem Mnasri, Fatma Tajini, Mustapha Trabelsi, Mohamed Elarbi Aouani, Ridha Mhamdi. Rhizobium gallicum as an efficient symbiont for bean cultivation. Agronomy for Sustainable Development, 2007, 27 (4), pp.331-336. hal-00886377

\section{HAL Id: hal-00886377 https://hal.science/hal-00886377}

Submitted on 1 Jan 2007

HAL is a multi-disciplinary open access archive for the deposit and dissemination of scientific research documents, whether they are published or not. The documents may come from teaching and research institutions in France or abroad, or from public or private research centers.
L'archive ouverte pluridisciplinaire HAL, est destinée au dépôt et à la diffusion de documents scientifiques de niveau recherche, publiés ou non, émanant des établissements d'enseignement et de recherche français ou étrangers, des laboratoires publics ou privés. 


\title{
Rhizobium gallicum as an efficient symbiont for bean cultivation
}

\author{
Bacem MNASRI $^{\mathrm{a}}$, Fatma TAJINI ${ }^{\mathrm{b}}$, Mustapha TRABELSI $^{\mathrm{b}}$, Mohamed Elarbi AOUANI $^{\mathrm{a}}$, Ridha MHAMDI $^{\mathrm{a} *}$ \\ ${ }^{a}$ Laboratoire Intéractions Légumineuses-Microorganismes, Centre de Biotechnologie de Borj-Cédria, BP 901, Hammam-Lif 2050, Tunisia \\ ${ }^{\mathrm{b}}$ École Supérieure d'Agriculture de Mateur, Bizerte, Tunisia
}

(Accepted 27 April 2007)

\begin{abstract}
Rhizobia are soil bacteria that fix atmospheric nitrogen in symbiosis with legumes in specialized organs called nodules. The legumes thus acquire the autonomy to grow in nitrogen-deficient soils. When nitrogen fixation by indigenous rhizobia is limited, field inoculation with efficient and competitive strains is an economically feasible way to increase production. When the inoculant is made from native strains of rhizobia the success of inoculation should be increased, since local strains are better adapted than commercial inoculants. Here, a Rhizobium gallicum strain, 8a3, previously selected for its competitiveness and symbiotic effectiveness with common bean under laboratory conditions, was tested in field trials in Tunisia. The experiments were conducted in six fields using three common bean cultivars. The majority of the fields showed a low density of the native rhizobia and inefficient nodulation by Sinorhizobium meliloti, a known symbiont of Medicago. Our results show that inoculation with $R$. gallicum strain $8 \mathrm{a} 3$ induced an increase in nodule numbers accompanied by a more than twofold increase in shoot dry yield. Monitoring of the nodulation occupancy through the fingerprinting of the repetitive extragenic palindromic sequences (REP-PCR) showed that strain 8a3 was competitive even in the soil showing a high population density of indigenous $R$. gallicum, and occupied more than $40 \%$ of the nodules. Moreover, in vitro antibiosis assays indicated that strain $8 \mathrm{a} 3$ produces antimicrobial activity on agar medium against indigenous common bean rhizobia, including the inefficient strains of $S$. meliloti. These results point out the benefits that could be achieved by selecting efficient and competitive strains among natural populations of rhizobia.
\end{abstract}

competitiveness / N2 fixation / Phaseolus vulgaris / Rhizobium gallicum

\section{INTRODUCTION}

Rhizobia are soil bacteria capable of inducing the formation of nitrogen-fixing nodules on the roots or stems of particular legume host plants (Spaink et al., 1998). The root nodule formation is the result of a complex molecule dialogue between rhizobia and legumes (Garg and Geetanjali, 2007). The symbiotic nitrogen fixation resulting from the rhizobialegume interaction can act as a renewable and environmentally sustainable source of nitrogen and can complement or replace fertilizer inputs (Peoples et al., 1995). Nitrogen offered by the bacteria is used directly by the plant, and so is less susceptible to volatilization, denitrification and leaching (Garg and Geetanjali, 2007).

Common bean (Phaseolus vulgaris L.) is an important food crop worldwide. However, it is classified among the least cultivated grain legumes in Tunisia. The low productivity of this crop has contributed to a progressive reduction in the area used for its cultivation, and currently national production does not cover more than $40 \%$ of consumption needs. A broad range of Rhizobium species are reported to nodulate this legume. However, bean is considered a poor nitrogen-fixing pulse in comparison with other grain legumes (Hardarson, 1993). Sparse nodulation and the lack of response to inoculation in field experiments has frequently been reported worldwide, raising questions about the benefits of inoculation (Graham, 1981;

\footnotetext{
*Corresponding author: ridha.mhamdi@ cbbc.rnrt.tn
}

Buttery et al., 1987). This fact is attributed to intrinsic characteristics of the host plant, particularly the nodulation promiscuity (Michielis et al., 1998), as well as the great sensitivity to other nodulation-limiting factors, such as the high rates of $\mathrm{N}$ fertilizer used in intensive agriculture, high temperatures and soil dryness (Graham, 1981).

In Tunisia we showed that $P$. vulgaris is nodulated by a diversity of species, including Rhizobium gallicum, $R$. leguminosarum bvs. phaseoli and viciae, R. etli, R. giardinii, Sinorhizobium fredii, S. meliloti and S. medicae (Mhamdi et al., 2002). $\mathrm{N}_{2}$-fixing nodulation was, however, found only in soils routinely cultivated with this legume. In the other soils, nodulation was very scarce or absent (Mhamdi et al., 1999). The nodules recovered from these regions were ineffective at $\mathrm{N}_{2}$ fixation and caused by non-specific nodulation with $S$. meliloti, $S$. medicae and bv. viciae of $R$. leguminosarum (Mhamdi et al., 2002). The promiscuous nodulation of common beans with non-specific rhizobia is probably the result of low abundance or absence of natural populations of bean-compatible rhizobia in the Tunisian soils. If so, inoculation of common beans with efficient and competitive rhizobial strains may be the means to improve biological $\mathrm{N}_{2}$ fixation and common bean productivity. However, inoculation trials conducted with the commercial strain $R$. tropici CIAT899 in the valley of Medjerda failed (Trabelsi, pers. com.).

Since native rhizobia are believed to be better adapted to local environmental conditions than commercial inoculants, we conducted a screening to select for the most efficient and 
competitive strains among indigenous rhizobia. The strain $8 \mathrm{a} 3$ of $R$. gallicum isolated from root nodules of common bean cultivated in Cap Bon was selected for its high symbiotic effectiveness (Mhamdi et al., 2002). The competitiveness of strain $8 \mathrm{a} 3$ on soil cores, monitored by using the reporter gene gusA, showed that this strain was highly competitive when inoculated into the cultivars Coco and Royalnel (Mrabet et al., 2005). The efficiency of utilization of this strain as an inoculant needs further confirmation under field conditions. On the other hand, the low productivity of common bean in Tunisia has led during recent years to the introduction of new cultivars. However, these cultivars were selected on the basis of simple agronomic characteristics and their symbiotic capabilities were generally neglected.

In this work, we aimed to assess the symbiotic effectiveness and competitiveness of strain $8 \mathrm{a} 3$ with these new cultivars in on-farm trials.

\section{MATERIALS AND METHODS}

\subsection{Field experiments}

On-farm trials were conducted in close partnership with farmers and extension services. They were replicated across farmers' fields but not within fields. Six farmers were selected according to their willingness to cooperate with the experiment (Tab. I).

The experimental design consisted of three treatments, not inoculated, inoculated and fertilized ( $50 \mathrm{~kg}$ of $\mathrm{NH}_{4} \mathrm{NO}_{3} / \mathrm{ha}$ ). Each treatment was subdivided into three subplots cultivated with three common bean cultivars, Coco, BRB17 and Flamingo. The subplots were $13.5 \mathrm{~m} \times 6 \mathrm{~m}$ in size and contained 30 rows. The sowing density was 20 seeds $/ \mathrm{m}^{2}$ $(10 \mathrm{~cm} / 50 \mathrm{~cm})$. A margin of $2 \mathrm{~m}$ separated the inoculated and the non-inoculated plots. The experiment was established in March 2005. The native strain 8a3 of R. gallicum bv. gallicum (Mhamdi et al., 2002) was grown to the late exponential phase in yeast-extract-mannitol broth (Vincent, 1970) and diluted to $1 / 20$ with well water (approximately $10^{8}$ bacteria $\mathrm{mL}^{-1}$ ). This suspension was used to inoculate the emerging seedlings using a watering can. Each subplot received 10 liters of inoculum along the seedling rows (approximately $5 \mathrm{~mL}$ for each seedling). Thirty plants were randomly collected from each subplot and used for nodule counting and shoot dry weight analysis at the flowering stage. Results were submitted to analysis of variance and mean comparison by the HSD test $(P<0.05)$.

\subsection{Characterization of indigenous rhizobia}

The abundance of indigenous populations of rhizobia nodulating common bean in each soil was estimated by the most probable number (MPN) method (Vincent, 1970). Native rhizobia were isolated from root nodules of common bean according to standard procedures (Mhamdi et al., 1999). Polymerase chain reaction coupled to restriction fragment length polymorphism (PCR-RFLP) of 16S rRNA genes was conducted on cells treated with proteinase $\mathrm{K}$ using primers fD1 and rD1 (Weisburg et al., 1991) according to the procedure described by Mhamdi et al. (2002). Digestion was performed by five endonucleases, MspI, NdeII, CfoI, HaeIII and $R s a \mathrm{I}$. Species assignation was done according to $16 \mathrm{~S}$ rDNA typing and comparison with the published database of mapped restriction sites in the 16S rRNA genes of rhizobia (Laguerre et al., 1997).

\subsection{Competitiveness monitoring}

Fingerprinting of the repetitive extragenic palindromic sequences amplified by polymerase chain reaction (REP-PCR) was used to monitor the nodulation occupancy by the introduced strain in the on-farm trials. The primers used were those described by Versalovic et al. (1991). Proteinase-treated cells were used as a DNA template for REP-PCR, as previously described (Zribi et al., 2004). The frequency of the REP-PCR pattern of strain $8 \mathrm{a} 3$ was estimated in the inoculated and noninoculated plots for the three cultivars used.

\subsection{In vitro antibiosis assay}

The overlay plate technique (Oresnik et al., 1999) was used to check the in vitro inhibition of the indigenous rhizobia by the introduced $R$. gallicum strain 8a3. Ten representatives from each indigenous species were tested. A saturated culture $(48 \mathrm{~h}$ old, $\mathrm{OD}_{630 \mathrm{~nm}}>1$ ) of the indicator strain (indigenous strain) grown in liquid tryptone-yeast extract medium (TY) was diluted to $10^{-3}$ in $5 \mathrm{~mL}$ of soft TY medium (1\% agar). The diluted suspension was poured on a solid TY ( $2 \%$ agar) layer in Petri dishes. Two hours later, $3 \mu \mathrm{L}$ of a saturated culture of the producing strain (strain 8a3) were inoculated onto the soft agar surface. Inhibition zones were measured after four days of incubation at $28{ }^{\circ} \mathrm{C}$. Each antibiosis test consisted of three replicates.

\section{RESULTS AND DISCUSSION}

\subsection{Diversity of indigenous rhizobia}

The density and the species diversity of the indigenous rhizobia nodulating common bean in the non-inoculated fields are given in Table II.

The density of the native rhizobia nodulating common bean was very low or null in the different fields, except in the Ben Mustapha soil. The 16S rDNA typing of field isolates showed that the native rhizobia isolated from the Ben Mustapha field were all assigned to $R$. gallicum. However, in the other soils, where nodulation was poor, a significant proportion of nodules were induced by non-specific nodulation by $S$. meliloti and $S$. fredii. Some Agrobacterium strains were also recovered from the Tej soil; however, they failed to re-nodulate their original host when re-examined for nodulation. This phenomenon 
Table I. Fields used for inoculation trials in this study.

\begin{tabular}{llll}
\hline Field & Climate & Irrigation practice & Cultivation history \\
\hline Ben Mustapha & Sub-humid & Irrigated & Potato, Common bean, Faba bean, Cereals \\
Tej & Sub-humid & Rain-fed & Faba bean, Chickpea, Cereals \\
Nassereddine & Sub-humid & Rain-fed & Cereals \\
Lazhar & Sub-humid & Rain-fed & Chickpea, Cereals \\
Mghraoui & Sub-humid & Irrigated & Potato \\
Mograne & Semi-arid & Irrigated & Experimental field (horticulture) \\
\hline
\end{tabular}

Table II. Density and species diversity of the indigenous rhizobia nodulating common bean in the different soils before inoculation. The numbers between parentheses indicate the number of samples in which each species occurred.

\begin{tabular}{lcl}
\hline \multirow{2}{*}{ Site } & \multicolumn{2}{c}{ Indigenous rhizobia nodulating common bean } \\
\cline { 2 - 3 } Ben Mustapha & High & Species diversity \\
Tej & Low & R. etlicum $(19 / 19)$ \\
Nassereddine & Low & S. meliloti $(20 / 20)$ \\
Lazhar & Null & None \\
Maghraoui & Low & R. gallicum $(11 / 20) ;$ S. meliloti $(9 / 20)$ \\
Mograne & Low & R. etli $(2 / 5) ;$ R. gallicum $(1 / 5) ;$ S. meliloti $(2 / 5)$ \\
\hline
\end{tabular}

* MPN, Most Probable Number (Vincent, 1970): high, $=10^{6}$ rhizobia $\mathrm{g}^{-1}$ soil; low, $<10^{3}$ rhizobia $^{-1}$ soil; null, below the detectable limit.

has been described by different authors (De Lajudie et al., 1999; Mhamdi et al., 2002; Hameed et al., 2004). Mhamdi et al. (2005) showed that these non-nodulating agrobacteria were able to colonize root nodules of common bean. Both rhizobia and agrobacteria co-existed in the infected nodules. The mechanism by which these isolates integrated nodules is still not known. More recently, Mrabet et al. (2006) found that Agrobacterium strains isolated from root nodules of common bean specifically reduce nodulation by $R$. gallicum in nonsterile soil samples and in vitro antibiosis assays. The introduced strain $8 \mathrm{a} 3$ was tested in in vitro antibiosis assays towards the agrobacteria recovered from Tej soil and was found to be highly sensitive. However, the extent of this impact on the introduced strain $8 \mathrm{a} 3$ needs to be evaluated further in field experiments.

\subsection{Inoculation yield}

The nodule numbers and the shoot dry yields of the three common bean cultivars in the six fields analyzed are given in Table III. Inoculation with $R$. gallicum $8 \mathrm{a} 3$ induced a significant increase in nodule number in all the fields and with the three cultivars. This increase was significant even in the Ben Mustapha soil where the density of the native rhizobia

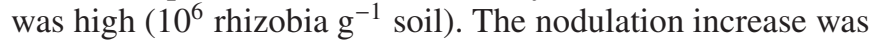
accompanied by a significant enhancement of the shoot dry yield in the different fields and with the different cultivars. More than a twofold increase was obtained in Ben Mustapha, Nassereddine, Lazhar and Mograne with the three cultivars. The shoot dry yields obtained in the irrigated fields, Ben Mustapha, Maghraoui and Mograne, were higher than those obtained in the non-irrigated fields. The introduced strain 8a3 induced an increase in nodule number even in Tej soil, which contained native populations of agrobacteria colonizing nodules. It seems that the density of these agrobacteria is not high enough to exercise a perceptible inhibition on the nodulation by the introduced strain.

\subsection{Competitiveness monitoring}

Analysis of nodule occupancy is a useful method for investigating the establishment, competitiveness and persistence of the introduced strains. Many technical approaches have been applied for this purpose. Inoculated strains have been monitored through antibiotic resistance (Ramirez et al., 1998), serological typing (Evans et al., 1996) or melanin production (Castro et al., 2000). Nevertheless, it has been proven that these techniques suffer from inaccuracy caused by instability or cross-reaction with indigenous rhizobia. Mrabet et al. (2005) used gus-labeled transconjugants to assess the competitiveness of the strain $8 \mathrm{a} 3$ under laboratory conditions. However, we did not use this gene labeling approach under field conditions because of environmental considerations. We adopted an approach based on the amplification by polymerase chain reaction of the repetitive extragenic palindromic sequences (REP-PCR). This technique has been shown to be highly discriminatory and suitable for evaluating intraspecific diversity of rhizobial strains (De Bruijn, 1992). However, this technique is laborious and expensive and could not be applied to large samples. This analysis was therefore only conducted on three fields, Ben Mustapha, Maghraoui and Mograne. These soils were selected because they contain 
Table III. Effect of inoculation with R. gallicum $8 \mathrm{a} 3$ in the different fields.

\begin{tabular}{|c|c|c|c|c|c|c|c|}
\hline \multirow[t]{2}{*}{ Site } & \multirow[t]{2}{*}{ Cultivar } & \multicolumn{3}{|c|}{ Nodule number } & \multicolumn{3}{|c|}{ Shoot dry weight (g/plant) } \\
\hline & & $\mathrm{T}_{0}$ & $\mathrm{~T}_{8 \mathrm{a} 3}$ & $\mathrm{~T}_{\mathrm{N}}$ & $\mathrm{T}_{0}$ & $\mathrm{~T}_{8 \mathrm{a} 3}$ & $\mathrm{~T}_{\mathrm{N}}$ \\
\hline \multirow[t]{3}{*}{ Ben Mustapha $^{I}$} & BRB17 & $21^{\mathrm{b}}$ & $35^{\mathrm{a}}$ & $4^{\mathrm{c}}$ & $2.0^{\mathrm{b}}$ & $4.4^{\mathrm{a}}$ & $3.5^{\mathrm{a}}$ \\
\hline & Coco & $24^{\mathrm{b}}$ & $35^{\mathrm{a}}$ & $7^{\mathrm{c}}$ & $3.0^{\mathrm{c}}$ & $9.7^{\mathrm{a}}$ & $7.5^{\mathrm{b}}$ \\
\hline & Flamingo & $21^{\mathrm{b}}$ & $58^{\mathrm{a}}$ & $5^{\mathrm{c}}$ & $4.0^{\mathrm{c}}$ & $9.7^{\mathrm{a}}$ & $7.5^{\mathrm{b}}$ \\
\hline \multirow[t]{3}{*}{ Tej } & BRB17 & $3^{\mathrm{b}}$ & $11^{\mathrm{a}}$ & $0^{\mathrm{b}}$ & $2.0^{\mathrm{b}}$ & $3.8^{\mathrm{a}}$ & $3.2^{\mathrm{a}}$ \\
\hline & Coco & $0^{\mathrm{b}}$ & $11^{\mathrm{a}}$ & $0^{\mathrm{b}}$ & $1.9^{\mathrm{c}}$ & $3.7^{\mathrm{a}}$ & $2.4^{\mathrm{b}}$ \\
\hline & Flamingo & $0^{\mathrm{b}}$ & $20^{\mathrm{a}}$ & $0^{\mathrm{b}}$ & $2.0^{\mathrm{c}}$ & $5.1^{\mathrm{a}}$ & $3.8^{\mathrm{b}}$ \\
\hline \multirow[t]{3}{*}{ Nassereddine } & BRB17 & $0^{\mathrm{b}}$ & $10^{\mathrm{a}}$ & $0^{\mathrm{b}}$ & $1.1^{\mathrm{b}}$ & $2.5^{\mathrm{a}}$ & $2.5^{\mathrm{a}}$ \\
\hline & Coco & $1^{\mathrm{b}}$ & $18^{\mathrm{a}}$ & $0^{\mathrm{b}}$ & $1.5^{\mathrm{b}}$ & $3.0^{\mathrm{a}}$ & $2.7^{\mathrm{a}}$ \\
\hline & Flamingo & $2^{\mathrm{b}}$ & $21^{\mathrm{a}}$ & $0^{\mathrm{b}}$ & $2.0^{\mathrm{c}}$ & $4.7^{\mathrm{a}}$ & $3.2^{\mathrm{b}}$ \\
\hline \multirow[t]{3}{*}{ Lazhar } & BRB17 & $0^{\mathrm{b}}$ & $12^{\mathrm{a}}$ & $0^{\mathrm{b}}$ & $0.9^{\mathrm{b}}$ & $2.0^{\mathrm{a}}$ & $2.1^{\mathrm{a}}$ \\
\hline & Coco & $0^{\mathrm{b}}$ & $12^{\mathrm{a}}$ & $0^{\mathrm{b}}$ & $1.1^{\mathrm{b}}$ & $4.3^{\mathrm{a}}$ & $3.4^{\mathrm{a}}$ \\
\hline & Flamingo & $0^{\mathrm{b}}$ & $17^{\mathrm{a}}$ & $0^{\mathrm{b}}$ & $1.9^{\mathrm{b}}$ & $4.7^{\mathrm{a}}$ & $4.3^{\mathrm{a}}$ \\
\hline \multirow[t]{3}{*}{ Maghraoui $^{\mathrm{I}}$} & BRB17 & nd & nd & nd & nd & nd & nd \\
\hline & Coco & $3^{\mathrm{b}}$ & $15^{\mathrm{a}}$ & $0^{\mathrm{b}}$ & $11.0^{\mathrm{c}}$ & $16.0^{\mathrm{a}}$ & $13.0^{\mathrm{b}}$ \\
\hline & Flamingo & $1^{\mathrm{b}}$ & $12^{\mathrm{a}}$ & $0^{\mathrm{b}}$ & $12.0^{\mathrm{c}}$ & $23.0^{\mathrm{a}}$ & $18.0^{\mathrm{b}}$ \\
\hline \multirow[t]{3}{*}{ Mograne ${ }^{I}$} & BRB17 & nd & nd & nd & nd & nd & nd \\
\hline & Coco & nd & nd & nd & nd & nd & nd \\
\hline & Flamingo & $0.5^{\mathrm{b}}$ & $27^{\mathrm{a}}$ & $0^{\mathrm{b}}$ & $4.9^{\mathrm{b}}$ & $11.0^{\mathrm{a}}$ & $8.9^{\mathrm{a}}$ \\
\hline
\end{tabular}

I This soil received a complement of irrigation according to plant need; $\mathrm{T}_{0}$, non-inoculated treatment; $\mathrm{T}_{8 \mathrm{a} 3}$, inoculated with $R$. gallicum strain $8 \mathrm{a} 3 ; \mathrm{T}_{\mathrm{N}}$, fertilized treatment. For each field and each cultivar, means with different letters are significantly different (HSD test, $\left.P<0.05\right)$.
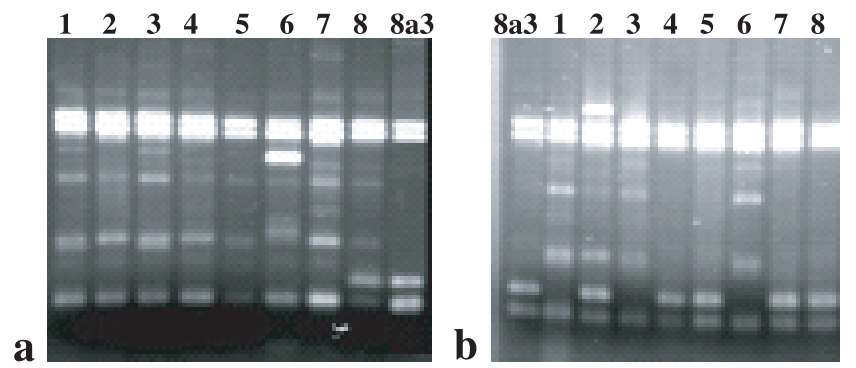

Figure 1. REP-PCR Fingerprinting of nodule isolates from the non-inoculated (a) and the inoculated (b) plots in the soil of Ben Mustapha. Lanes 1-8, different isolates from each plot; 8a3, REPPCR pattern given by $R$. gallicum strain 8a3. REP-PCR: repetitive extragenic palindromic sequences amplified by polymerase chain reaction.

native populations of rhizobia nodulating common bean of the same species as the inoculant. This situation may inhibit the establishment of the introduced strain and the success of inoculation (Kamicher and Brill, 1986). Figure 1 shows examples of REP-PCR printing of nodule isolates from the inoculated and the non-inoculated plots. The nodule occupancy levels as determined according to the frequency of the REP-PCR pattern of the $8 \mathrm{a} 3$ strain are given in Table IV.
The REP-PCR typing of nodules recovered from the noninoculated plot in Ben Mustapha showed that the REP-PCR 8 a3 type was identified in 3/99 of the nodules analyzed. However, in the inoculated treatment, the REP-PCR 8a3 type represented 45/99 of the nodules analyzed, thus giving nodule occupancy of $42 \%$. In the Maghraoui field, where the few nodules observed in the non-inoculated plot were induced by $R$. gallicum and $S$. meliloti, the REP-PCR 8 a3 type was found in 2/30 of the nodules. In the inoculated plot, all the nodules tested showed the same REP-PCR $8 \mathrm{a} 3$ type. The nodule occupancy by $8 \mathrm{a} 3$ was thus higher than $90 \%$. In Mograne soil, very few nodules were obtained with the non-inoculated plants. The REP-PCR 8 a3 type was detected only in the inoculated treatment, where it represented $100 \%$.

In vitro antibiosis assays by the overlay plate technique indicated that strain $8 \mathrm{a} 3$ exercises an antagonistic activity against all the tested strains of indigenous rhizobia from the species $R$. gallicum, R. etli, S. meliloti and S. fredii.

These results point out the benefits that could be achieved by selecting efficient and competitive strains among natural populations of rhizobia. However, these inoculation trials need to be replicated in separate experiments. The establishment and the persistence of the introduced strain need to be monitored for several years. The antimicrobial activity of this strain may play an important role in interspecific and intraspecific 
Table IV. Nodule occupancy by the inoculated strain $8 \mathrm{a} 3$ of $R$. gallicum as estimated by REP-PCR profiling under field conditions.

\begin{tabular}{|c|c|c|c|c|}
\hline \multirow[t]{2}{*}{ Site } & \multirow[t]{2}{*}{ Cultivar } & \multicolumn{2}{|c|}{$\begin{array}{c}\text { Frequency of the REP-pattern } \\
\text { of } R \text {. gallicum strain } 8 \mathrm{a} 3\end{array}$} & \multirow[t]{2}{*}{$\begin{array}{l}\text { Nodule occupancy by the } \\
\text { inoculated strain (\%) }\end{array}$} \\
\hline & & Non-inoculated & Inoculated & \\
\hline \multirow[t]{4}{*}{ Ben Mustapha } & BRB17 & $2 / 33$ & $16 / 33$ & 42 \\
\hline & Coco & $1 / 33$ & $11 / 33$ & 30 \\
\hline & Flamingo & $0 / 33$ & $18 / 33$ & 54 \\
\hline & All cvs. & $3 / 99$ & $45 / 99$ & 42 \\
\hline \multirow[t]{4}{*}{ Maghraoui } & BRB17 & nd & nd & nd \\
\hline & Coco & $0 / 15$ & $15 / 15$ & 100 \\
\hline & Flamingo & $2 / 15$ & $15 / 15$ & 87 \\
\hline & All cvs. & $2 / 30$ & $30 / 30$ & 93 \\
\hline \multirow[t]{4}{*}{ Mograne } & BRB17 & nd & nd & nd \\
\hline & Coco & nd & nd & nd \\
\hline & Flamingo & $0 / 5$ & $30 / 30$ & 100 \\
\hline & All cvs. & $0 / 5$ & $30 / 30$ & 100 \\
\hline
\end{tabular}

nd, not determined.

competition, and their importance in soil microbial diversity needs to be investigated further.

\section{CONCLUSION}

Optimal performance of N-fixing symbiosis depends upon pre-selection of both symbiotic partners for adaptation to the target environment, which may in some form present a challenge to rhizobial survival or nodulation. When the inoculant is made from native strains of rhizobia the success of inoculation should be increased, since local strains are better adapted than commercial inoculants. The utilization of $R$. gallicum strain $8 \mathrm{a} 3$ as inoculant in different soils demonstrated the ability of this strain to outcompete indigenous populations of rhizobia of the same species and to occupy a high proportion of nodules.

Acknowledgements: This work was supported by grants from the Aquarhiz project (FP6 INCO-CT-2004-509115).

\section{REFERENCES}

Buttery B.R., Park S.J., Findlay W.J. (1987) Growth and yield of white bean (Phaseolus vulgaris L.) in response to nitrogen, phosphorus and potassium fertilizer and to inoculation with Rhizobium, Can. J. Plant Sci. 67, 425-432.

Castro S., Carrera I., Martinez-Drets G. (2000) Methods to evaluate nodulation competitiveness between Sinorhizobium meliloti strains using melanin production as a marker, J. Microbiol. Meth. 41, 173-177.

De Bruijn F.J. (1992) Use of repetitive sequences and the polymerase chain reaction to fingerprint the genomes of Rhizobium meliloti isolates and other soil bacteria, Appl. Environ. Microb. 58, 2180-2187.

De Lajudie P., Willems A., Nick G., Mohamed S.H., Torck U., Coopman R., Filali-Maltouf A., Kersters K., Dreyfus B., Lindstrom K., Gillis
M. (1999) Agrobacterium bv. 1 strains isolated from nodules of tropical legumes, Syst. Appl. Microbiol. 22, 119-132.

Evans J., Gregory A., Dobrowski N., Morris S.G., O'connor G.E., Wallace C. (1996) Nodulation of field-grown Pisum sativum and Vicia faba: competitiveness of inoculant strains of Rhizobium leguminosarum bv. viciae determined by indirect competitive ELISA method, Soil Biol. Biochem. 28, 247-255.

Garg N., Geetanjali (2007) Symbiotic nitrogen fixation in legume nodules: process and signalling: a review, Agron. Sustain. Dev. 27, 59-68.

Graham P.H. (1981) Some problems of nodulation and symbiotic nitrogen fixation in Phaseolus vulgaris L.: a review, Field Crop. Res. 4, 93-112.

Hameed S., Yasmin S., Malik K.A., Zafar Y., Hafeez F. (2004) Rhizobium, Bradyrhizobium and Agrobacterium strains isolated from cultivated legumes, Biol. Fert. Soils 39, 179-185.

Hardarson G. (1993). Methods for enhancing symbiotic nitrogen fixation, Plant Soil 152, 1-7.

Kamicker B.J., Brill W.J. (1986) Identification of Bradyrhizobium japonicum nodule isolates from Wisconsin soybean farms, Appl. Environ. Microb. 51, 487-492.

Laguerre G., van Berkum P., Amarger N., Prevost D. (1997) Genetic diversity of rhizobial symbionts isolated from legume species within the genera Astragalus, Oxytropis, and Onobrychis, Appl. Environ. Microb. 63, 4748-4758.

Mhamdi R., Jebara M., Aouani M.E., Ghrir R., Mars M. (1999) Genotypic diversity and symbiotic effectiveness of rhizobia isolated from root nodules of Phaseolus vulgaris L., grown in Tunisian soils, Biol. Fert. Soils 28, 313-320.

Mhamdi R., Laguerre G., Aouani M.E., Mars M., Amarger N. (2002) Different species and symbiotic genotypes of field rhizobia can nodulate Phaseolus vulgaris in Tunisian soils, FEMS Microbiol. Ecol. 41, 77-84.

Mhamdi R., Mrabet M., Laguerre G., Tiwari R., Aouani M.E. (2005) Colonization of Phaseolus vulgaris nodules by Agrobacterium-like strains, Can. J. Microbiol. 51, 105-111. 
Michielis J., Dombrecht B., Vermeiren N., Xi C., Luyten E., Vanderleyden J. (1998) P. vulgaris is a non-selective host for nodulation, FEMS Microbiol. Ecol. 26, 193-205.

Mrabet M., Mhamdi R., Tajini F., Tiwari R., Trabelsi M., Aouani M.E. (2005) Competitiveness and symbiotic effectiveness of a Rhizobium gallicum strain isolated from root nodules of Phaseolus vulgaris, Eur. J. Agron. 22, 209-216.

Mrabet M., Mnasri B., Ben Romdhane S., Laguerre G., Aouani M.E., Mhamdi R. (2006) Agrobacterium strains isolated from root nodules of common bean specifically reduce nodulation by Rhizobium gallicum, FEMS Microbiol. Ecol. 56, 304-309.

Oresnik I.J., Twelker S., Hynes M.F. (1999) Cloning and characterization of a Rhizobium leguminosarum gene encoding a bacteriocin with similarities to RTX toxins., Appl. Environ. Microb. 65, 2833-2840.

Peoples M.B., Herridge D.F., Ladha J.K. (1995) Biological nitrogen fixation: An efficient source of nitrogen for sustainable agricultural production, Plant Soil 174, 3-28.
Ramirez M.E., Israel D.W., Wollum A.G. (1998) Using spontaneous antibiotic-resistant mutants to assess competitiveness of bradyrhizobial inoculants for nodulation of soybean, Can. J. Microbiol. 44, $753-758$.

Spaink H.P., Kondorosi A., Hooykaas P.J.J. (1998) The Rhizobiaceae, Kluwer Academic Publishers, Dordrecht, The Netherlands.

Versalovic J., Koeuth T., Lupski J.R. (1991) Distribution of repetitive DNA sequences in Eubacteria and application to fingerprinting of bacterial genomes, Nucleic Acids Res. 19, 6823-6831.

Vincent J.M. (1970) A manual for practical study of root nodule bacteria, IBP Handbook, Blackwell Scientific Publications, Oxford.

Weisburg W., Barns S.M., Pelletier D.A., Lane D.J. (1991) 16S ribosomal DNA amplification for phylogenetic study, J. Bacteriol. 173, 697-703.

Zribi K., Mhamdi R., Huguet T., Aouani M.E. (2004) Distribution and genetic diversity of rhizobia nodulating natural populations of Medicago truncatula in Tunisian soils, Soil Biol. Biochem. 36, 903-908. 